\title{
Impact of Forging Conditions on Plasma Nitrided Hot-forging Dies and Punches
}

\author{
Ravindra Kumar ${ }^{1}$, Ram Prakash², J. Alphonsa ${ }^{3}$, Jalaj Jain ${ }^{2}$, A. Pareek ${ }^{4}$, P. A. Rayjada ${ }^{3}$, \\ P. M. Raole ${ }^{3} \&$ S. Mukherjee ${ }^{3}$ \\ ${ }^{1}$ Birla Institute of Technology, (Ranchi), Jaipur Centre, 27-Malviya Industrial Area, Jaipur, Rajasthan, India \\ ${ }^{2}$ CSIR-Centre for Electronics Engineering and Research Institute (CEERI) Pilani-333031, Rajasthan, India \\ ${ }^{3}$ Facilitation Center for Industrial Plasma Technologies-Institute for Plasma Research (FCIPT-IPR), \\ Gandhinagar, Gujarat, India \\ ${ }^{4}$ National Engineering Industries Pvt. Ltd., Khatipura Road, Jaipur -302 006, Rajasthan, India \\ Correspondence: Ravindra Kumar, Birla Institute of Technology, 27-Malviya Industrial Area, Jaipur 302017 , \\ Rajasthan, India. E-mail: ravindrauniversal@yahoo.com
}

Received: February 2, 2012 Accepted: February 13, 2012 Online Published: August 15, 2012

doi:10.5539/jmsr.v1n4p11 URL: http://dx.doi.org/10.5539/jmsr.v1n4p11

\begin{abstract}
In this work an effort has been made to study the effect on the performance of the plasma nitrided AISI H13 hot-forging dies and punches in two different forging service conditions -namely, fully-automatic and semi-automatic processes. The plasma nitriding is performed to increase the surface properties like -wear resistance and surface hardness of these components. After plasma nitriding the surface hardness of these materials has increased typically from $\sim 500 \mathrm{HV}_{0.01}$ to $\sim 1200 \mathrm{HV}_{0.01}$. In the plasma nitriding process high-voltage electrical energy is used to form plasma through which nitrogen ions are accelerated to impinge on the workpiece. The ion bombardment heats the workpiece, cleans the surface, and provides active nitrogen to make iron-nitride compounds. The iron-nitride compounds then diffuse to the workspace to harden the surface. In these two service conditions the plasma nitrided hot-forging dies and punches have shown typically 2.5 to 4 times increment during the performance. It is observed that the increment in the performance of the dies and punches depends on the forging service conditions, i.e., temperature of the dies and punches, shot repetition time and effective cooling of dies and punches in service conditions. Four times increment in the performance of dies and punches is found in the semi-automatic process, whereas two and half times increment in performance of dies and punches is observed in the fully-automatic process.
\end{abstract}

Keywords: AISI-H13 hot-work tool steel, plasma nitriding, micro-hardness, hot-forging dies

\section{PACS:}

81.65.Lp

81.40.Ef

52.40.Hf

\section{Introduction}

The well-known AISI H11 and AISI H13 steels are frequently used for making casting-dies, hot-forging dies and punches (Smith,1993; Miola et al., 1999; ASM Metal Handbook, 1990), due to their excellent properties like high toughness, high hardenability and good machineability (Kheirandish \& Noorian, 2008). The AISI H13 steel has enough red hardness (i.e., resistance to deformation at higher operating temperature) to retain its properties at high operating temperature. It shows many excellent properties but in normal conditions it has poor wear resistance and lower surface hardness which results in reduced performance in the stringent service conditions, such as, higher operating load, higher operating temperature and corrosive environment (Zhang \& Zhu, 1993). Also the thermal shock (i.e., frequently repetition of heating and cooling) increases the thermal stress. In fact, under the stringent service conditions, the contact surface of dies and punches tends to wear out faster than the other parts (Visuttipitukul \& Kuwahara, 2006). The continuous friction damages the surface very fast in 
corrosive environment. For this reason, surface treatment is essentially needed in order to increase the surface hardness and improve the wear resistance of tools (i.e., dies and punches) in the stringent conditions.

Many conventional methods for surface modifications are available in the market, such as, gas nitriding (Mirdha, 2007), liquid nitriding (Davis, 2002), chrome plating (Morkhov \& Egorova, 1965), etc. All these techniques are avoided now a day because they pollute environment. At present plasma nitriding technique is receiving a great attention due to controlled process, single step operation, excellent dimensional stability of the nitrided components and the fact that it is an environment-friendly technique (Ravindra Kumar et al., 2011; Insup Lee \& Jeong, 2008). The plasma nitriding is a thermo-chemical process which improves the surface properties, such as surface hardness, wear resistance, corrosion resistance, and fatigue strength of various engineering steel components (Borgioli et al., 2003; Bell et al., 2000; Hoppe, 1998; Podgornik et al., 1998). Hence the plasma nitriding is performed on AISI H13 steel in the present study.

Some research work has been published on the plasma nitriding of hot-forging dies (Mehmet et al., 2000; Leite et al., 2010) but no attention has been paid so far to study the impact of hot-forging conditions on plasma nitrided dies and punches in the real forging service conditions. So an effort has been made here to study the impact of hot-forging conditions on plasma nitrided hot-forging dies and punches in two different media, namely, fully-automatic and semi-automatic processes. Media are differentiated on the basis of heating and cooling time between the two successive shots, frequency of the shots per minutes and impact load to forge the components.

\section{Details of Hot-forging Conditions}

\subsection{Condition-1 (Fully-automatic)}

In the fully-automatic condition, the hot-forging dies and punches are used to forge the bearing races. The dies and punches were fixed horizontally in forging press "Siemens Semitic OP 17". Combined press load in this process was kept at $2500 \mathrm{kN}$ and frequency of shot repetition was $\sim 0.5$ seconds. The average speed of final product that comes out from the forging press is $\sim 110$ pieces/minute when the process is fully automatic. The observed temperatures on the inner surface of dies and on the outer surface of the punches were $\sim 800-850{ }^{\circ} \mathrm{C}$ and $\sim 600-650{ }^{\circ} \mathrm{C}$, respectively during the forging operation, while the temperature of the forged bar was kept $\sim 1150-1200{ }^{\circ} \mathrm{C}$. In this process the cooling was provided continuously to the dies and punches. It is seen that, due to the high speed of the process (i.e., shot repetition time), the effect of the cooling was negligible on the inner portion of the die and on the outer surface of the punch. The component clearance size of the forge components (bearing races in our case) was kept $\pm 0.5 \mathrm{~mm}$.

\subsection{Condition-2 (Semi-automatic)}

In the semi-automatic condition also, the hot-forging dies and punches are used to forge the similar bearing races. However, in this process one uses vertical forging press with combined press load at $2500 \mathrm{kN}$ and shot repetition time depends on the operator choice so that complete process is semi-automatic. The average speed of the press was kept $\sim 10$ pieces/minute so that in semi-automatic process the shot repetition time is very large $(\sim 6$ seconds) and a sufficient time is available for cooling. Consequently, it has been observed that due to the availability of sufficient time for cooling, the temperatures on the inner surface of dies and on the outer surface of punches could reach only $\sim 550-600{ }^{\circ} \mathrm{C}$ and $\sim 400-450{ }^{\circ} \mathrm{C}$, respectively, during the forging operation. In this case also the component clearance size of the forge components was kept $\pm 0.5 \mathrm{~mm}$.

It is to be emphasized that if the size of the forged components was beyond the clearance limit $\pm 0.5 \mathrm{~mm}$, the dies and punches were no more used. Hence the number of components forged by a die or a punch within this clearance limit is the criteria to fix the performance of die or punch in fully-automatic or semi-automatic service conditions. So the performance of the untreated (i.e., simple heat treated) and plasma nitrided dies and punches has been evaluated by the number of forged components to see the performance in both fully-automatic and semi-automatic service conditions.

\section{Experimental Procedure}

\subsection{Sample Preparation}

Components used for assessment in this study were commercially available AISI H13 hot-forging dies and punches. The chemical composition of this standard steel is given in the Table 1. Hot-forging dies and punches used have diameters $7 \mathrm{~cm}$ and $6.5 \mathrm{~cm}$, respectively. Before plasma nitriding, the heat-treatments were carried out on the hot-forging dies and punches as listed in the Table 2 . These heat treated components were polished with $\mathrm{SiC}$ emery papers of $240,320,400,600,800$ grit size and samples were prepared to study the untreated and 
plasma nitrided components. After polishing, the prepared components were also rinsed with acetone, washed and dried.

Table 1. Chemical composition of AISI H13 steel in (wt \%)

\begin{tabular}{ccccccccc}
\hline $\mathrm{C}$ & $\mathrm{Cr}$ & $\mathrm{Mn}$ & $\mathrm{P}$ & $\mathrm{Si}$ & $\mathrm{S}$ & $\mathrm{Mo}$ & $\mathrm{V}$ & $\mathrm{Fe}$ \\
\hline $0.37-0.42$ & $5.0-5.50$ & $0.20-0.50$ & 0.025 & $0.80-1.20$ & 0.025 & $1.20-1.75$ & $0.80-1.20$ & Balance \\
\hline
\end{tabular}

Table 2. Different Heat-treatments carried on AISI H13 steel

\begin{tabular}{cccc}
\hline Treatment type & Conditions & Microstructure & Initial Hardness \\
\hline Preheating/Annealing & Heating- $800^{\circ} \mathrm{C}$ for 2 hrs & Ferrite, perlite and & $200 \mathrm{HV}$ \\
& $-720{ }^{\circ} \mathrm{C}$ for $4 \mathrm{hrs}$ & carbides & \\
Quenched & Heating: $\sim 1050^{\circ} \mathrm{C}$ & Martensite, and small & $650 \mathrm{HV}$ \\
& Soaking time: 1 inch $/$ hour & amount of fine & \\
Quenching: Forced air & carbides & \\
cooling & & \\
Heating: $\sim 550^{\circ} \mathrm{C}$ & Tempered martensite, & $480 \mathrm{HV}$ \\
& Soaking time: 1 inch $/$ hour & and fine carbides & \\
Cooling: up to room & & \\
Temperature & & \\
& & & \\
& &
\end{tabular}

\subsection{Plasma Nitriding Experimental Set-up}

Plasma nitriding is carried out in a large working volume $(800 \mathrm{~mm}$ diameter and $800 \mathrm{~mm}$ height $)$ plasma nitriding system with necessary arrangement of vacuum pumps and auxiliary heaters. A schematic diagram of plasma ion nitriding system is shown in Figure 1 . The chamber is evacuated up to the base pressure $5 \times 10^{-3} \mathrm{mbar}$ with the help of rotary and root pumps. The samples were sputtered with argon and hydrogen gas at the ratio of 1:4 and at a pressure of 1 mbar. The gas pressure was measured by Baratron gauge. At this working pressure, 30 $\mathrm{kHz}$ pulse dc power source was used to ignite the plasma. The Argon-Hydrogen plasma removes the contaminants from the surface during the cleaning process. After an hour, plasma nitriding process was carried in the Nitrogen-Hydrogen gas environment. The typical working pressure was $\sim 3$ mbar and Hydrogen to Nitrogen gas ratio was kept 80:20. The plasma nitriding process parameters to nitride the AISI H13 hot-forging dies and punches are given in the Table 3.

Table 3. Process parameters of plasma nitriding process

\begin{tabular}{ccccc}
\hline Temperature in ${ }^{\circ} \mathrm{C}$ & Pressure in mbar & $\begin{array}{c}\text { Gas ratio } \\
\mathrm{N}_{2}: \mathrm{H}_{2} \%\end{array}$ & Time duration & $\begin{array}{c}\text { Voltage in } \\
\text { Volts }\end{array}$ \\
\hline $515-520$ & 3 & $20: 80$ & 18 Hour & $510-520$ \\
\hline
\end{tabular}




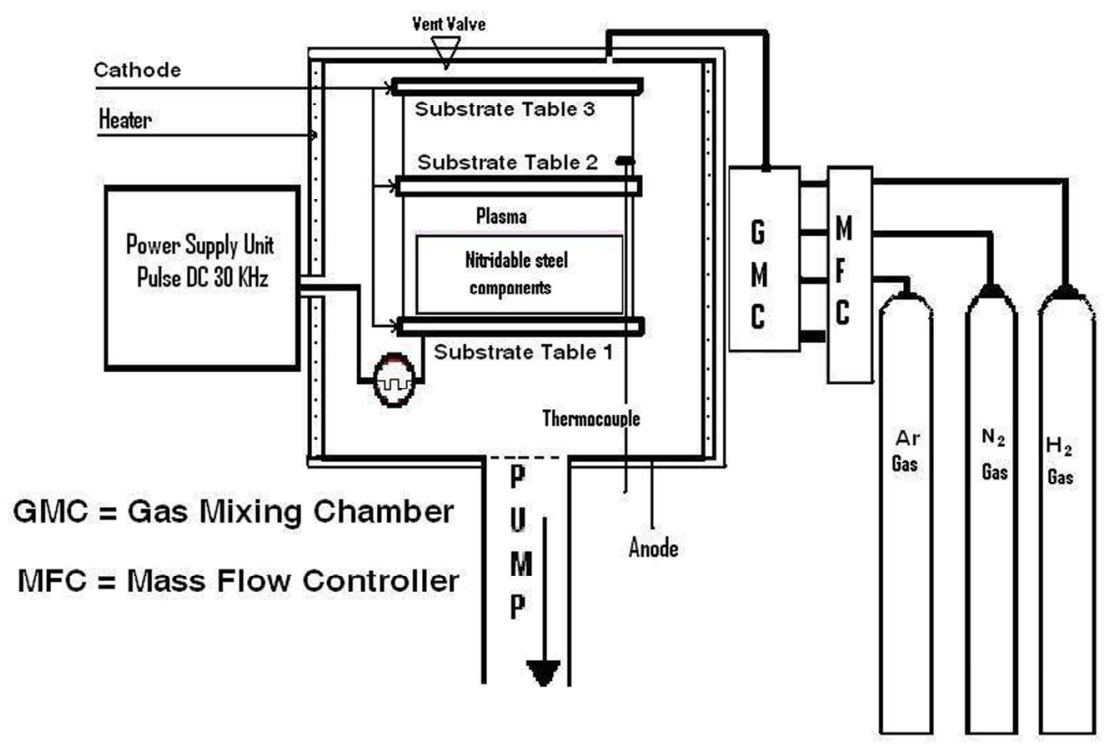

Figure 1. Block diagram of the plasma nitriding system

\subsection{Characterization Techniques Used}

Microhardness measurements were performed on the surface of untreated and plasma nitride components with a Leitz Vickers Hardness tester using a load of $100 \mathrm{gm}$ and a dwell time of $20 \mathrm{~s}$. Case depth of the modified layer has been examined by Clemex Meophot-32 make optical microscope at a magnification of $200 \times$. The depth of modified layer was measured under the optical microscope by etching the samples with $2 \%$ Nital. X-ray diffraction (XRD) has been used in powder mode. Seifert made XRD-3000 PTS Diffractometer with Cu anode $\mathrm{x}$-ray at $40 \mathrm{kV}$ and $30 \mathrm{~mA}$ for $\mathrm{Cu} \mathrm{K} \alpha$ radiation $(\lambda=1.5418 \AA)$ was used. The diffraction patterns were obtained in the $2 \theta$ ranges of $30-90^{\circ}$ with the step size of $0.1^{\circ}$ and counting time of $3 \mathrm{~s}$ per step.

\section{Results and Discussion}

\subsection{Results of Untreated and Plasma Nitrided Dies and Punches}

\subsubsection{Microstructure Study}

The untreated AISI H13 steels showed the tempered martensite, and fine carbides structures under the optical microscope as shown in the Figure 2. After plasma nitriding of the components, a cross-section of the sample was taken which was polished to observe it under the optical microscope. Plasma nitrided sample with $20 \%$ nitrogen and $80 \%$ hydrogen gas has shown $\sim 200 \mu \mathrm{m}$ diffusion zone (see Figure 3 ) and without any white layer. In the plasma nitrided sample, the diffusion zone has different microstructure from the bulk region's microstructure. It is due to the formation of phases (like, $-\mathrm{Fe}_{4} \mathrm{~N}, \mathrm{Fe}_{3} \mathrm{~N}, \mathrm{CrN}$ etc) during the plasma nitriding process. The phase formations are also confirmed by the x-ray diffraction analysis, which can be seen in the Figure 5.

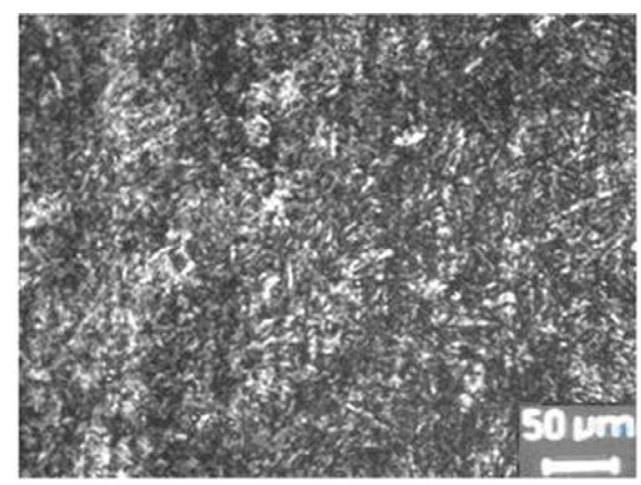

Figure 2. Micro-structural view of the untreated sample 


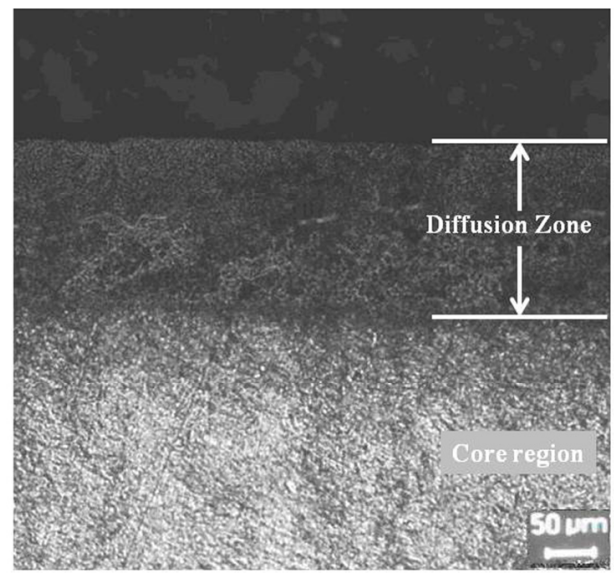

Figure 3. Micro-structural view of plasma nitrided sample for $20 \%$ Nitrogen and $80 \%$ Hydrogen gas compositions

\subsubsection{Micro-hardness Measurement with Depth Profile}

Figure 4 shows the micro-hardness case depth profile of untreated and plasma nitrided samples. The untreated samples show the uniform micro-hardness $\sim 480 \mathrm{HV}$ from surface to core region. In the plasma nitrided samples around $1200 \mathrm{HV}$ micro-hardness has been achieved at the surface. Measurement of micro-hardness with respect to depth has shown continuous decrease in the micro-hardness value from surface to core region. The decreasing value in the micro-hardness from surface to core region is due to the reduction in the percentage of nitrogen from surface to core region during the diffusion process (Yoon-Kee et al., 2001). The micro-hardness of plasma nitrided samples has been measured after every $10 \mu \mathrm{m}$ from surface to core region. The effective case depth of around $200 \mu \mathrm{m}$ has also been estimated from the micro-hardness depth profile measurement.

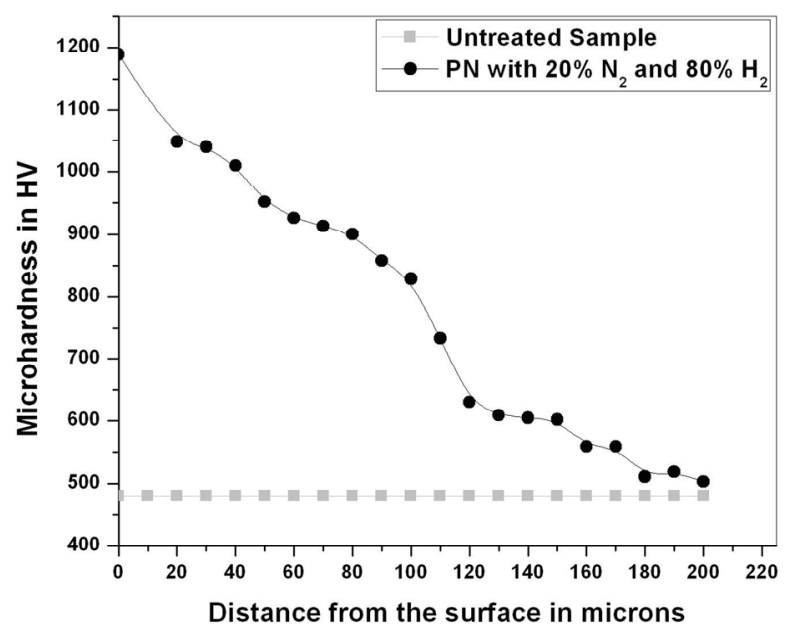

Figure 4. Microhardness depth profile measurement of untreated and plasma nitrided samples

\subsubsection{X-ray Diffraction Analysis}

$\mathrm{X}$-ray diffraction analysis has been carried out to get information about new phase formation on the surface after the plasma nitriding process. Figure 5 shows the observed peaks on an untreated and plasma nitrided sample. The untreated sample showed broadened ferrite peaks whereas plasma nitriding led to the formation of iron nitride and chromium nitride compounds like $\mathrm{Fe}_{4} \mathrm{~N}, \mathrm{Fe}_{3} \mathrm{~N}, \mathrm{CrN}$, etc. and their relative abundance depends on the treatment temperature. 


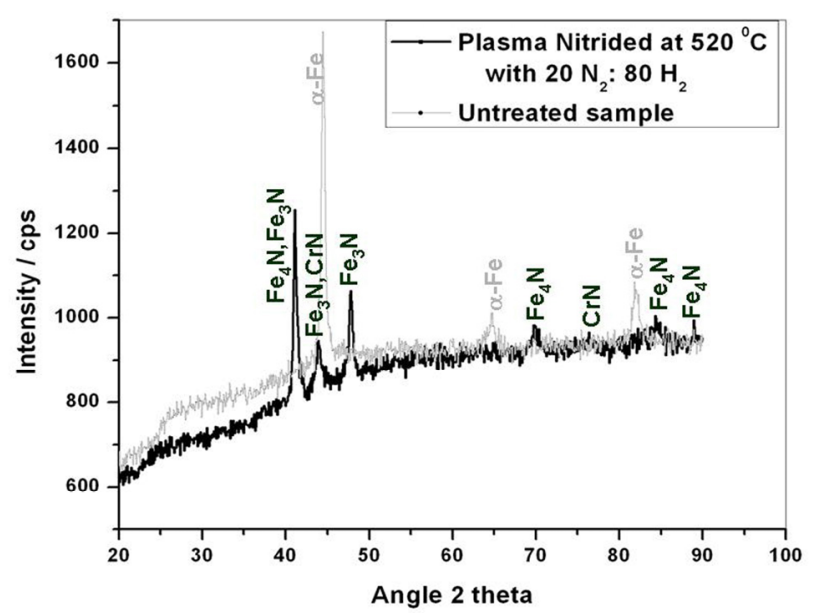

Figure 5. XRD pattern of the untreated and plasma nitrided samples

\subsection{Results of Untreated and Plasma Nitrided Dies and Punches in the Service Conditions and Impact of Hot-forging Conditions}

The results obtained during two hot-forging conditions namely fully-automatic (condition-1) and semi-automatic (condition-2) on plasma nitrided dies and punches in the service conditions are given in Table 4. The comparison of service condition 1 with 2 shows the batter performance of dies and punches in the service condition 2 . Four times increment in the performance of dies and punches is seen in the semi-automatic process whereas two and half times increment in the performance is seen in the fully-automatic process. In the service condition- 2 , the temperatures on the inner surface of dies and outer surface of punches has reached typically $\sim 550-600^{\circ} \mathrm{C}$ and $\sim 400-450^{\circ} \mathrm{C}$, respectively whereas in service condition- 1 the temperatures reached $\sim 800-850^{\circ} \mathrm{C}$ and $\sim 600-650^{\circ} \mathrm{C}$, respectively. At higher temperature nitrogen start to decompose and it can no longer protect the surface from wear out. This obviously can lead in reduced performance in service condition-1. Furthermore, in service condition- 1 the frequency of shot repetition $(\sim 0.5$ seconds) is faster ( 1 order of magnitude) in comparison to the service condition-2 ( $\sim 6$ seconds), which can restrict the effective cooling of dies and punches in condition-1. Also at higher surface temperature a shielded region might form between the tools surface and coolant, which can further restrict the effective cooling.

From these observations it can be argued that the surface temperature plays an important role in the increasing performance of the dies and punches in the service conditions. Surface temperature is further related with the shot repetition time and effective cooling. So, if the forging temperature is above than the plasma nitriding temperature, the outward diffusion of nitrogen starts from the surface of dies and punches, which reduces the surface hardness of the plasma nitrided components when used in the service condition. This suggests that the proper cooling time or new cooling mechanism is essentially needed to increase the performance of the dies and punches in the certain stringent service conditions.

Table 4. Number of forged component by untreated and plasma nitrided dies and punches

\begin{tabular}{|c|c|c|c|c|c|}
\hline $\begin{array}{l}\text { Hot-forging } \\
\text { conditions }\end{array}$ & $\begin{array}{l}\text { Number of } \\
\text { components forged } \\
\text { by Untreated Dies } \\
\text { (simple } \\
\text { heat-treated) } \\
\text { (no.) }\end{array}$ & $\begin{array}{l}\text { Number } \\
\text { components } \\
\text { by forged } \\
\text { Punches } \\
\text { heat-treated) (no.) }\end{array}$ & $\begin{array}{l}\text { Number of } \\
\text { components } \\
\text { forged by Plasma } \\
\text { Nitrided Dies } \\
\text { (no.) }\end{array}$ & $\begin{array}{l}\text { Number of } \\
\text { components } \\
\text { forged by } \\
\text { Plasma Nitrided } \\
\text { Punches } \\
\text { (no.) }\end{array}$ & $\begin{array}{l}\text { Effective } \\
\text { increment } \\
\text { performance }\end{array}$ \\
\hline $\begin{array}{l}\text { Condition-1 } \\
\text { (fully-automatic) }\end{array}$ & $1500-1600$ & $2500-2800$ & $3800-4000$ & $5800-6200$ & $\sim 2.5$ times \\
\hline $\begin{array}{l}\text { Condition-2 } \\
\text { (semi-automatic) }\end{array}$ & $1800-2000$ & $2700-2900$ & $7000-7400$ & $9600-10000$ & $\sim 4$ times \\
\hline
\end{tabular}




\section{Conclusion}

The performance of the plasma nitrided AISI H13 hot-forging dies and punches in two different forging service conditions - namely, fully-automatic and semi-automatic processes have been studied. From the performance measurement testing, under forging conditions, it is concluded that the performance of plasma nitrided components of dies and punches under the fully-automatic service condition is typically 2.5 times than untreated components while the performance in the semi-automatic service conditions it is typically of the order of 4 . The variation in the performances of the dies and punches in two different service conditions are due the variation in the surface temperature of the dies and punches. To enhance the performance of dies and punches in the stringent service conditions the identifications of proper cooling time or new cooling mechanism are under the scope of further studies.

\section{Acknowledgement}

The authors thankfully acknowledge Department of Science and Technology (DST) Govt. of India for the financial support for this work under project Ref. No. ST(RJ)/DP/2K6/445.

\section{References}

ASM International. (1990). ASM Metal Handbook, 1, 439-444.

Bell, T., Sun, Y., \& Suhadi, A. (2000). Environmental and technological aspects of plasma nitrocarburising. Vacuum, 59, 14-23. http://dx.doi.org/10.1016/S0042-207X(00)00250-5

Borgioli, F., Galvanetteo, E., Fossati, A., \& Bacci, T. (2003). Glow-discharge nitriding and post-oxidising treatments of AISI H11 steel. Surf. and Coat. Tech., 162, 61-66. http://dx.doi.org/10.1016/S0257-8972(02)00574-1

Davis, J. R. (2002). Surface Hardening of Steels: Understanding the Basics. ASM International.

Hoppe S. (1998). Fundamentals and applications of the combination of plasma nitrocarburizing and oxidizing. Surf. and Coat. Tech., 1199-1204. http://dx.doi.org/10.1016/S0257-8972(97)00548-3

Kheirandish, S., \& Noorian, A. (2008). Effect of niobium on microstructure of cast AISI H13 hot work tool steel, Jour. of Iron and Steel Research, International, 15(4), 61-66. http://dx.doi.org/10.1016/S1006-706X(08)60145-4

Kim, Yoon-Kee, Baek, Jong-Moon, \& Lee, Keun-Ho. (2001). Plasma diagnostics of pulsed d.c. glow discharge combined with ICP for deep nitriding process. Surf. and Coat. Tech., 142-144, 321-327. http://dx.doi.org/10.1016/S0257-8972(01)01083-0

Lee, Insup, \& Jeong, Kwang-Ho. (2008). Plasma post oxidation of plasma nitrocarburized SKD 61 steel. $J$. Mater. Sci. Technol., 24(1), 136-138.

Leite, M. V., Figueroa, C. A., Corujeira Gallo, S., Rovani, A. C., Basso, R. L.,O., Mei, P. R., Baumvol, I. J. R., \& Sinatora, A. (2010). Wear mechanisms and microstructure of pulsed plasma nitrided AISI H13 tool steel. Wear, 269, 466-472.

Mehmet, Capa, Muzaffer, Tamer, Turgut, Gulmez, \& Cengiz Tahir, Bodur. (2000). Life enhancement of hot-forging dies by plasma-nitriding. Turk J Engin Environ Sci, 24, 111-117.

Miola, E. J., de Souza, S. D., Olzon-Dionysio, M., Spinelli, D., \& dos Santos, C. A. (1999). Nitriding of H-12 tool steel by direct-current and pulsed plasmas. Surf. and Coat. Tech., 116-119, 347-351.

Mirdha, S. (2007). Gas nitriding of En40B steel with highest growth rate of the case and reduced white layer formation, International Journal of Microstructure and Material Properties, 2, 54-63. http://dx.doi.org/10.1504/IJMMP.2007.012938

Morkhov, M. I., \& Egorova, K. A. (1965). Chrome-plating of piston rings. J. Chemical and Petroleum Engineering, 1, 144-145. http://dx.doi.org/10.1007/BF01145734

Podgornik, B., Vizntin, J., \& Leskovsek, V. (1998). Tribological properties of plasma and pulse plasma nitrided AISI 4140 steel. Surf. and Coat. Tech., 108-109, 454-460. http://dx.doi.org/10.1016/S0257-8972(98)00571-4

Ravindra, Kumar, Alphonsa, J., Ram, Prakash, Boob, K. S., Ghanshyam, J., Rayjada, P. A., Raole, P. M., \& Mukherjee, S. (2011). Plasma nitriding of AISI 52100 ball bearing steel and effect of heat treatment on nitrided layer. Bull. Mater. Sci., 34, 153-159. http://dx.doi.org/10.1007/s12034-011-0065-9

Smith W. F. (1993). Structure and Properties of Engineering Alloys (2nd ed.). McGraw Hill, 405- 409. 
Visuttipitukul, P., Paa-rai, C., \& Kuwahara, H. (2006). Charactrization of plasma nitrided AISI H13 tool steel. Acta Metallurgica Slovaca, 12, 264-274.

Zhang, S., \& Zhu, W. (1993). TiN coating of tool steels: a review. Jour. of Materials Processing Technology, 39, 165-177. http://dx.doi.org/10.1016/0924-0136(93)90016-Y 